\title{
Dominions apart: Scandal and sporting mismatch in Australian-South African association football encounters, $1947-1955^{1}$
}

\begin{abstract}
South Africa, Australia and New Zealand participated in numerous sporting contests prior to World War Two. These encounters were primarily on cricket pitches and rugby fields. After nearly four decades of negotiations the first association football matches were played between the three countries in 1947. The first tour was plagued by scandal on and off the pitch and despite this Australia returned the favour three years later. Another five years would pass before South African returned to Australia, by which time it was clear that a large gulf had emerged between Australia and South Africa in terms of sporting ability and organisational efficiency. This article focuses on the three tours of 1947, 1950 and 1955, dissecting each as they occurred against a backdrop of scandal, organisational inefficiency and sporting mismatch.
\end{abstract}

\section{Introduction}
'We come as ambassadors with a view to cementing the bonds of friendship between South Africans, Australians and New Zealanders which were so pronounced between the three Dominions during the war'.2 James Barbour, manager of the 1947 South African team.

South Africa, Australia and New Zealand were three-quarters of the old 'white' colonial Empire, yet with the modern game of football having existed for nearly a century these countries had never crossed swords except for perhaps the odd game 
through their military friendship forged in Europe. As Barbour stated, the bonds of the battle field could be transposed to that of the playing fields. Yet while the intention was to bring together these former colonies through football, within a decade their paths would diverge significantly in football terms and a short while later politically. This divergence was created through a number of factors, yet, significantly, it would be distance, overconfidence and a poor administration of the sport that would lead Australia into near isolationism while South Africa would initially proceed with great promise.

This article discusses the emergence of contacts and football tours between Australia, New Zealand and South Africa, contacts that were initiated in the context of the British Empire and her Dominions. Despite the initial discussions of 1909 between Australian, New Zealand and South African officials, the first tour to Australia and New Zealand only commenced after the end of the Second World War. A second tour to South Africa followed shortly afterwards and this cemented the bonds of Empire against the backdrop of apartheid in South Africa and a 'White' Australia. Yet the final tour of 1955 saw football in South Africa and Australia develop along different paths. Academic studies have generally focussed on cricket and rugby contacts between Australia, New Zealand and South Africa. ${ }^{3}$ These studies are important and have provided valuable analysis in understanding sporting contacts between the three countries, an analysis that has, however, masked other sporting relations and underplayed or ignored those sports’ significance within the overall tri-nation context. ${ }^{4}$ By considering football relations between the three countries, we identify the struggle to maintain contact within the context of a disintegrating Empire, an emerging apartheid South Africa and the quest to play football. 


\section{The emergence of organised football in South Africa and Australia}

A range of national sports organisations were established in South Africa in the late 1880s and early 1890s. ${ }^{5}$ These included associations for cricket, rugby and football amongst others. The South African Football Association (SAFA) was established in 1892. A goal of these organisations was to host British touring sides and send South African teams to Britain. The rationale was to popularise the game at home, improve the standard of play, foster and maintain the links between South Africa and Britain and significantly, generate profits for the local associations. In cricket, an English eleven captained by R. G. Warton toured South Africa in 1888-9. ${ }^{6}$ A second English team captained by W. W. Read toured in 1891-2. While in 1895-6 and 1898-9 Lord Hawke led his English side to South Africa. South African cricket sides toured England in 1894, 1901, 1904 and 1907. In rugby, W. E. Maclagan led a side comprised of English and Scottish players to South Africa in 1891. A second British side toured in 1896 and again in 1903. A South African rugby team toured Britain and France in $1906 .^{7}$ These contacts and tours fostered important sporting links that generated financial returns for the associations. More significantly, however, is that they played a crucial political role in consolidating the notion of the British Empire and fostered an emerging 'white' South African identity, particularly after the South African War (1899-1902). ${ }^{8}$ Furthermore, in the early twentieth century, South Africa turned to Australia and New Zealand to expand its sporting relationships. Australian cricketers first played in South Africa in 1902-3 while South Africa toured Australia in 1910-11. An Australian military association football team and a New Zealand Services Team team played in South Africa in 1919 and a South African rugby team 
first played in New Zealand in 1921 while the New Zealanders returned to South Africa in $1928 .^{9}$

Australia and New Zealand were considered a long way from the Home Country. Blainey emphasizes, in The Tyranny of Distance, a number of problems that lay before these emerging nations. ${ }^{10}$ Yet, sport was unmistakeably missing in his analysis and in the late nineteenth century and the early decades of the twentieth century distance became the main source of concern for Australia's sporting bodies attempting to create, and maintain, sporting ties with Britain. More significantly, it was the cost of travelling and of being away from home that meant those sports which were financially inadequate struggled to find a way to defray the costs of either sending players overseas or sponsoring those from a far land. For Association football, unlike the two rugby codes, a strong organisation was not present until the mid-1920s. ${ }^{11}$ In addition, ‘... [association] football also failed to become officially established as an institution of Empire'. ${ }^{12}$ Thus any opportunity to properly organise, or even generate funding for, a visit from England, or any nation outside of the western Pacific domain, was highly unlikely.

Australia, though, retained strong ties with Britain. Through the two rugby codes and cricket, Australians were continuously exposed to the English maintaining their contact with their distant 'home'. Stoddart saw this as the British transferring their dominant beliefs of social behaviour, standards, relations and conformity on the colonies. Yet while these events created competition between the Empire and its colonies, authority would be maintained in England. ${ }^{13}$ Thus Australians, as with the other colonial states, endeavoured to show themselves as equal, or superior, through 
sport. This they were successful at in cricket and eventually in both the rugby codes. ${ }^{14}$ For the most popular of football codes, Association football, Australia was lagging, and more so behind the rest of the Empire.

Throughout the Empire, association football existed as soon as the new rules were formed in 1863. Although Australian historians tend to differ, recent evidence shows variants of association football existing as early as the mid-1870s in Brisbane. ${ }^{15}$ Colonial associations were founded from the early 1880s, ${ }^{16}$ while it took until Christmas 1911 before any semblance of a national body, the Commonwealth Football Association (CFA), was created to organise the game in Australia. ${ }^{17}$ Although the Australians rules game had its own Council set up in the 1906, the CFA was the first of the British football codes to merge under one body. Rugby league followed in 1924 and rugby union waited until 1949 to form its own national body. ${ }^{18}$ The new association football body, though, was unable to organise any international matches.

The CFA was placed in limbo in 1915, re-emerging as a re-constituted Association in 1921 and through this new body international exchanges became common throughout the inter-war period. Although the Association's primary intention was to organise an English tour of Australia, openings became available to invite countries from all over the world to send teams to Australia. By the time a combined amateur-professional English team arrived in 1925, Australia had already contested Test series, with varied success, against two other Dominions in New Zealand and Canada as well as a representative team from China. ${ }^{19}$ The Australian organisers, thus, recognised the importance of pitting their own against the English. Yet they were to be severely 
outclassed, the English winning every match on tour. ${ }^{20}$ Despite these loses, Australia remained active in the international sphere participating in tours abroad including the Netherlands East Indies (1928 and 1931) and New Zealand (1933) and at home receiving Czechoslovakia and China (1927), New Zealand (1936) the English Amateurs (1937) India (1938), Palestine (1939) and a Hong Kong team in $1941 .^{21}$

The matches against the Chinese and India are of interest to 'race' historians for Australia's open door policy to 'non-white' sporting bodies was inconsistent with its more restrictive white Australia policy. The latter, formalised in 1901, not only restricted immigration, it marginalised 'non-whites' already living in Australia. ${ }^{22}$ Sport, though appeared to sit outside of the policy and as tours were relatively brief, the Australian government tolerated the 'non-white' sportsmen. In 1908 AfricanAmerican pugilist Jack Johnson fought Tommy Burns in Sydney. The Fijian cricket tour of 1907-08, the 1930-31 West Indian cricket tour and the football tours already mentioned demonstrated the government's relaxation of its racist laws when sport was involved..$^{23}$

\section{Australian and South African football contact}

In early 1909, South African football officials accepted an invitation from the New Zealand Football Association (NZFA) to tour the country and Australia. ${ }^{24}$ However, later that year the NZFA postponed the venture. ${ }^{25}$ During this period negotiations were undertaken with the English FA which resulted in the first tour by a representative English team to South Africa in 1910. An English FA team visited South Africa again in 1920 and SAFA sent its first representative team to Europe in 
1924. In 1925 the NZFA again invited the South Africans to tour their country. ${ }^{26}$ Before the dust could settle from the English visit to Australia in 1925, initial negotiations had commenced between the Australian, New Zealand and South African authorities concerning football exchanges. ${ }^{27}$ SAFA resolved to negotiate with the NZFA about a possible tour in 1927 or 1928 . This tour did not materialise and the Scottish professional team Aberdeen visited South Africa in 1927. In the same year correspondence between SAFA and the Australian Soccer Football Association (ASFA) discussed the possibility of an Australian team touring the country in 1928 and a South African team Australia in $1929 .{ }^{28}$ However, at the 1927 SAFA AGM it was noted that sending a South African side to Australia would prove financially difficult while inviting an Australian team to South Africa would not be feasible as the New Zealand rugby All Blacks would be touring in 1928 and an English FA would visit again in 1929. South Africa offered to visit Australia in 1928 but the English rugby league team was also touring. For the NSWSFA it meant that 'unless, therefore, Australia is able to invite a South African team next year, there is little prospect of an early exchange of visits between South Africa and Australia'. ${ }^{29}$ The South Africans noted that ' ... it was hoped at some future date to be able to arrange for an exchange or visits'. ${ }^{30}$ Despite SAFA's reluctance to tour Australia and New Zealand or invite teams from the Dominions, the Transvaal FA suggested a tour to New Zealand would 'benefit the game in this country' in spite of the planned tour by the All Blacks. ${ }^{31}$ In early 1928 SAFA resolved not to invite or tour Australia and New Zealand. Despite this setback, the NZFA lobbied the English FA to support tours of the Dominions. SAFA supported the initiative of the NZFA and suggested a tentative programme of tours that planned for the forthcoming years in advance would 'avoid overlapping in communications... and the uncertainty at present experienced of being 
able to arrange such visits and tours when desired,. ${ }^{32}$ The South African football authorities continued to discuss possible tours from Australia and New Zealand with their counterparts. It became increasingly evident that they displayed a preference for visits of professional and amateur sides from Europe. Motherwell visited South Africa in 1931 and 1934, the Combined Services (1935), the Vienna Athletic Club (1936), Aberdeen (1937) and the English FA (1939). Moreover, SAFA refused to accept an invitation from football authorities in Java to tour because 'it would mean playing against coloured players'. ${ }^{33}$ In 1936 the Australian football authorities invited SAFA and the English FA to tour in 1937. Once the English FA accepted the offer correspondence with SAFA ceased and nothing came of the invitation. In 1938, at the annual conference of the ASFA, a five-year plan was formulated which involved South Africa to visit in 1939 and Australia to travel across the Indian ocean the following year. ${ }^{34}$ In 1939, this was pushed back a year and even with war having taken hold of Europe, South Africa still wanted to tour in $1940 .{ }^{35}$ Yet, Australia, having suffered poor touring teams from India (1938) and Palestine (1939), were concerned about the quality of the South Africans and considered sending an official to view whether the South Africans were good enough to tour Australia. ${ }^{36}$ The Australians again invited South Africa to tour and SAFA agreed in principle to tour in 1939. ${ }^{37}$ Due to the outbreak of war discussions were suspended.

\section{The 1947 South African tour of Australia and New Zealand}

Within months of the end of World War Two the Australians again invited SAFA to send a touring side to Australia and New Zealand. SAFA accepted the invitation and honoured the agreement that had been negotiated prior to the war. ${ }^{38}$ Three trial 
matches were held in South Africa in 1946 to select the touring party. Nomination lists were sent to SAFA affiliates who voted on the manager, assistant manager and trainer. The team was named in November 1946. The Rand Daily Mail published a report from Australian football official F. R. Druery in which he maintained:

'the Australian standard to-day is not as good as pre-war...the style of play could not be considered typically English, it is in effect a combination of ruggedness and polish with an unbeaten attitude, even to the last minute of the game... Australia is particularly anxious to try conclusions with South Africa as they feel that they must defeat or near defeat South Africa before they could expect to receive an invitation to play in England...Australia has suffered because of the war, but now that peace is again with us, our young players are beginning to spring forth. ${ }^{39}$

The South Africans departed for Australia while King George VI and Queen Elizabeth were touring South Africa consolidating notions of Commonwealth and the Dominions. The South African team travelled on the S.S. Misr which was also transporting '600 alien immigrants' ${ }^{40}$ to Australia. Prior to the departure in Durban, SAFA official S.V. Kimber stated that the:

'progress of the tour will be watched with keen interest...you will emulate the highest tradition of sportsmanship on and off the field...this tour is the first soccer one from South Africa to Sister Dominions, and in the true sense becomes a national visit. Therefore you are not only representing South Africa as sportsmen but in all too important role as true sons and citizens of this Country...we know that the best team has been selected to wear the Springbok 
colours, which will be worthily worn to the honour of South Africa. You will be accorded a very hearty welcome... and you will make many friendships that will closer the ties of bondship between our respective Countries' ${ }^{41}$

Sponsorships were received from the United Tobacco Company who supplied team members 'with cigarettes for the whole tour', ${ }^{42}$ Consol Footwear supplied football boots to the players and the Vulcan Rubber Works supplied training shoes. Fourteen of the eighteen man team were ex-service men and in Australia the team participated in an ANZAC parade. Over 100 spectators turned out to watch the tourists in the first training session. In their first official function Perth Mayor, Frank Smith remarked 'that the visit of the South Africans would be more than a soccer tour and it would help cement the two units of Empire' ${ }^{43}$ By the time the tourists had reached the eastern coast of Australia, it was evident that the side was able to hold its own. Druery stated the South Africans were the best players to have visited since the English professional visit of $1925 .{ }^{44}$ The South Africans were however increasingly unhappy with their Australian hosts' tour arrangements. South African manager, Barbour requested to be informed of all accommodation arrangements. He felt 'sanitary arrangements were primitive' in Perth, while in Adelaide the team slept up to seven in a room. ${ }^{45}$ In addition, a South African player is reported to have 'told the manager of the hotel that he would not even have put his Native servant in similar quarters' ${ }^{46}$ Barbour suggested his teams' dissatisfaction 'might have a bad effect on their game'. ${ }^{47}$ Barbour stated 'judging by the way we have been herded round Australia, the officials must have thought we were a lot of Zulus. When a team visits South Africa the very best accommodation and travelling conditions are provided. Surely the same could be done in Australia’. ${ }^{48}$ The South Africans travelled by train between 
Perth and Adelaide while the Australian team flew by plane. ${ }^{49}$ The South Africans not only complained about matters off the field but also on the field in terms of the smaller pitches that had been prepared by their hosts and the type of footballs used. The smaller pitches suited the 'vigorous, robust, hard kicking tactics of the Australians'.50 The South African journalist Reg Wright, travelling with the team, wrote that Barbour could have shown 'more diplomacy and patience [which] would have been smoothed away and much of the adverse publicity could have been avoided' ${ }^{51}$ In contrast the Sydney Sun suggested that 'the conversion of men, who could have been enthusiastic ambassadors, into embittered critics indicates an incredible degree of short-sightedness in the Australian soccer officials [and] could easily do great injury to the friendly relationships between the two Dominions...the South Africans were compelled to accept cheap dormitory conditions, bad food and inferior service'. 52 The Daily Telegraph reported that 'some members of the (SA) team said yesterday that they felt they had been misled about Australia's reputation as a sporting host'. ${ }^{53}$ Moreover, Barbour stated 'we did not come here to show you how to play football. We are not professionals. We came as South Africans and ambassadors of our country' ${ }^{54}$ Despite the controversies on and off the pitch, the South Africans attracted close to 40000 in the Test match in Sydney. The Star reported '...the Springboks have captured the popular imagination' ${ }^{55}$ Not only had large crowds watched the South Africans play but handsome profits were generated too. After six matches 90000 spectators had paid over $£ 10,000$ to watch the team. ${ }^{56}$ Yet as the tour progressed, the South Africans continued to court controversy. Prior to their final Test against Australia, the South African managers requested three referees' names be submitted to their team. The visitors would then select the referee for the final match which was the practice in South Africa. ${ }^{57}$ This was against the 
backdrop of the South African managers being 'incensed at decisions made in internationals' and the 'dissatisfaction...[in] the way recent Test matches [were] handled ${ }^{58}$ Australian selector Sid Blake stated that the 'Springbok officials presented an ultimatum that they would not play the fifth Test unless McWilliams was displaced as referee. I considered it a bluff and held out strongly that he be retained' ${ }^{59}$ The South African request was refused. In their final match prior to the departure for New Zealand, the South Africans encountered 'several unpleasant incidents and the referee called the captains together' ${ }^{60}$ Barbour undiplomatically remarked that 'we shall not meet with such robust play in New Zealand'. ${ }^{61}$

As preparations were finalised for the tour to New Zealand, the issue of race and the composition of opposing teams emerged. Within South Africa, racial segregation and discrimination in all spheres of life was entrenched. In football, SAFA's Constitution and Rules clearly stated that members, players and referees had to be 'of full European descent' ${ }^{62}$ Reg Wright reported in The Star that '....it is almost certain that the Springbok soccer side will meet teams with a fair sprinkling of Maoris’ ${ }^{63}$ Barbour remarked that 'of course we will play against Maoris. We will be following the policy of Springbok Rugby sides when touring here...the Maoris do not generally shine to soccer...In addition to meeting Maoris it is possible one or two Tongos [sic] (Polynesians) may win places against the Springboks. These fuzzy haired black people from the Pacific Isle are said to be good soccer players' ${ }^{64}$ South African rugby’s 'policy’ on playing against Maoris was not as clear cut as suggested by Barbour. Parekura Tureia and Nathaniel Arthur 'Ranji’ Wilson were excluded from the 1919 touring New Zealand Services Team [rugby] of South Africa because Tureia’s Maori heritage and Wilson’s Anglo-West Indian heritage. ${ }^{65}$ During the first 
South African rugby tour of New Zealand in 1921, Charles Blackett, a South African press correspondent wrote a cable intended for South Africa in which stated 'it was bad enough having to play against a team officially designated "New Zealand Natives” but the spectacle of thousands of Europeans frantically cheering on a band of coloured men to defeat members of their own race was too much for the Springboks, who were frankly disgusted' ${ }^{66}$ The cable was leaked to the press and published in the Napier Daily Telegraph. Despite Harold Bennett, the South African manager disassociating his team from the cable the damage had been done. ${ }^{67}$ When the New Zealand rugby team toured South Africa in 1928, it did so without any Maori players after they had been excluded from trial matches. ${ }^{68}$ Despite the initial comments made by South African journalists and tour management, nothing further developed in regards to race and the composition of teams, rather the issue of amateurism and professionalism dominated the headlines.

While the South African footballers were in New Zealand in 1947, The Christchurch Star-Sun published an article that would define the tour and leave lasting bitterness for all parties. The newspaper reported that the tourists were 'so disgusted... with Australian ideas of sportsmanship' and Barbour is quoted to have said 'none of us ever wants to see Australia again' ${ }^{69}$ Barbour maintained that

'if we had known that Soccer in Australia is professional, we would never have gone there... we are insistent on the difference between amateur and professional sport...members of our team get $£ 3$ a week out-of-pocket expenses, and we got a shock when we learned that the Australian players 
were getting $£ 12$ a match, with hotel accommodation and all expenses thrown in'. $^{70}$

Moreover he remarked 'from what we saw of it, there is no real sport in Australia...the whole set-up is rotten with money. There is a lot of betting on the outcome of matches. We objected to the man who refereed all the Test matches. Some of his decisions were quite obviously unfair and when they could not beat us, they set out in the last couple of games to maim us' ${ }^{71}$ The ASFA Chairman Sydney Storey was quoted in the South African press, and suggested comments were 'too absurd for words... and [Barbour] a most difficult man to deal with as distinct from other members of the party’. ${ }^{72}$ The Star noted that Malcolm Taylor (assistant manager), Horace Smethurst (the captain) and Cecil Kurkland (the vice-captain) and the whole team publicity distanced themselves from the remarks of Barbour. ${ }^{73}$ The Australian press reported that the souring of relations could have repercussions for other sporting contacts between the two countries. ${ }^{74}$ The animosity continued when Australian official and selector Blake referred to Barbour as 'ungrateful and unappreciative [and] the South Africans knew every trick of the game and gave nothing away’. ${ }^{75}$ Barbour, though, maintained that he gave no press interview nor did anyone hear him make the statements. ${ }^{76}$ A cable was sent by Smethurst and Kurkland to SAFA which stated: 'satisfied press article did manager gross injustice. We affirm our loyalty and support'. ${ }^{77}$ Yet in the Daily Telegraph Barbour denies a slur on Australians, but states that 'any criticism I have made has been levelled specifically against New South Wales Soccer officials and their action in paying players and playing the same team against us in most matches' ${ }^{78}$ Despite the scandal engulfing the tour off the field, the South Africans continued to play well, undefeated throughout New Zealand including 
a 6:0 result in the second Test in front of 10,000 spectators. The South Africans returned to Australia and played a series of matches against local opposition but refused to play any further internationals. The South Africans were in Australia and New Zealand for four months and the Rand Daily Mail reported that wives of many of the players had suffered economic hardships due to the length of the absence of the players. On their return to South Africa, SAFA were keen for the team to play an exhibition match against a South African XI. This would recover many of the financial losses incurred by SAFA during the Clyde FC tour of South Africa at the same time. The Star exclaimed 'our soccer players [are] probably the best in the Dominions [and] would be an immense draw card'. ${ }^{79}$ The management and players however felt otherwise. Up to six of the players had agreed to take unpaid leave during the duration of the tour and two had become fathers while away. Moreover 'the married men in particular, are worried and depressed. The enforced prolongation of their stay here is not a happy holiday. It is an anxious time for all [and] they are toying with the idea of taking temporary work' in Australia until their return to South Africa. $^{80}$

The SAFA held a special meeting to discuss the incidents that occurred on tour. Barbour and Taylor submitted separate reports of the tour to the SAFA executive. Barbour's report was circulated amongst football officials in Natal. Rather than deal with the report at the special meeting, SAFA established a committee of inquiry to consider the report. ${ }^{81}$ As a consequence A.S. Henning of the Frontier Football Association claimed to have 'lost confidence in the president and executive of SAFA' in not dealing with the report at the meeting. ${ }^{82}$ At a special general meeting held the following year, and all records of the enquiry were 'sealed and filed' ${ }^{83}$ Barbour had 
informed SAFA early in 1948 that he would retire from football and not stand for reelection. ${ }^{84}$ As a consequence, SAFA agreed 'that no direct action be taken' however should Barbour be involved in football again the report would 'be re-opened and disciplinary action taken’ against him. ${ }^{85}$

The expenditure on the 1947 tour exceeded revenue by $£ 1017.10 .11 .^{86}$ Despite the financial concerns and scandals that engulfed the 1947 tour, the South Africans played in front of 210000 spectators in Australia who paid $£ 24000 .^{87}$ The South Africans dominated and won 28 of the 33 games played while only losing twice, one the final International. ${ }^{88}$ According to Wright the team 'played intelligent, bright, short-passing positional soccer' ${ }^{89}$ He attributed this to the number of British sides that had toured South Africa as compared to those from outside of Britain who had toured Australia which was 'short-sighted [as] it has given Australia the thrill of beating all comers it has deprived their players of the chance of learning from masters' ${ }^{90}$

\section{The 1950 Australian tour of South Africa and Southern Rhodesia}

Australia believed it had made great strides with the final home Test win against South Africa and football authorities were keen to arrange further tours. The English FA invited all Dominions to a meeting at the time of the 1948 London Olympic Games. The FA viewed the idea of tours between Britain and the Dominions on similar lines to those of cricket and rugby union. ${ }^{91}$ The representatives from the Dominions suggested a six-year touring plan involving the four British associations. For Australia, its representative at the conference, Sydney Storey, stated 'Australian 
Soccer is now much closer to English standards than when the professional team was here in 1925 ' re-enforcing the commentary put forward just prior to the war of the suitability of Australia's opponents. ${ }^{92}$ Yet, as with the plans of 1938, this too did not materialise and it became left for the Dominions to fend for themselves.

South Africa and Australia maintained communications. In late 1948 an invitation by Australia for a second South African tour was declined ${ }^{93}$ and after persistent attempts in February of 1949 by the Australians, SAFA officially rejected the invitation. ${ }^{94}$ Tensions existed within SAFA as certain officials viewed South Africa as the best Dominion side and were keen to play against professional British teams. Other officials wanted to cement the Dominion ties by inviting representative amateur teams to South Africa. ${ }^{95}$ An avenue was opened for the Southern Transvaal Football Association to send a team to Australia, but that did not materialise. ${ }^{96}$ Eventually, in late October 1949, South Africa proposed that the Australians should travel, based on the earlier decision that within three years of the 1947 tour Australia should visit its sister Dominion. ${ }^{97}$ By November the invitation was accepted and work commenced for the first trip by another Dominion football side to South Africa. ${ }^{98}$

The opening few months of 1950 were hectic for the Australian authorities. While the loss of defender Joe Marston to Preston North End in England ${ }^{99}$ was a blow, other matters concerning the itinerary were being discussed. Numerous versions were created with one including a match in Lourenço Marques, Mozambique and a trip to the Victoria Falls. ${ }^{100}$ When the team was selected at the end of February, four of the States were represented, Queensland delivering the captain, Bob Lawrie, and one of the two managers, Harold Barwick. New South Wales attained the largest of the 
representation and the other manager, Dave Johnston. ${ }^{101}$ The team sailed from Fremantle on the Arawa in early May. ${ }^{102}$

The team was welcomed in Pretoria by the Chairman of SAFA and many of the local football supporters. ${ }^{103}$ Yet while the officials, the players and the fans were all excited about the game, certain sections of the media were somewhat scathing about the whole idea. From as early as February, the South African media displayed concerns about the tour and stated that certain provinces were keen for it not to materialize. ${ }^{104}$ These thoughts continued upon arrival with The Star football reporter, Reg Wright, stating that 'the Australians do not play like professionals', that 'they cannot compare to some of the football machines such as Motherwell which have toured and humbled South African soccer' and finally that there 'are many technical flaws in their game'. ${ }^{105}$ Eric Litchfield of the Rand Daily Mail compared what he believed would be the defence of the Australians to the infamous 1932-33 English cricket tour of Australia. 'I should prefer to call it body-line because the Australians throw in everything in a desperate effort to save their goal'. ${ }^{106}$

Thoughts, and commentary, though, would soon turn to the games being played and the fact that the Australians were actually holding their own, winning most matches. At the conclusion of the 18-match tour, the Australians had defeated their opponents ten times, with five losses and three draws. They scored 85 goals and conceded $28 .^{107}$ South Africa were victorious 3-2 and 2-1 in the opening two Tests but Australia won 2-1 and 2-0 in the other two to square the series. ${ }^{108}$ With South Africa having been more successful in 1947, the hosts were said to have held the Ashes following their second win. ${ }^{109}$ One reason for the turnaround was highlighted prior to the tour's 
commencement by Australia's centre-forward, Frank Parsons. He stated that the results would come owing to 'the advantage of having developed team-work by playing together throughout the tour' ${ }^{110}$ While team-work, together with the mateship attained through living together for such a long time, was significant, Australia chose a counter-tactic to the 'third-back' system that South Africa employed successfully. The Australian selectors chose two centre-forwards instead of just one and the South African failed to respond this new threat. ${ }^{111}$ The Australians did have their problems, suffering numerous injuries. For one, Victorian Jack Wilson, his injury led to blood poisoning. A request made by the Australians for a replacement player was denied by SAFA owing to 'too many impracticalities'. ${ }^{112}$ Nevertheless, this did not affect the Australians.

The Australians played in front of segregated fans in South African stadiums. Black South Africans keenly followed touring teams in the country and in the 1930s they learnt new tactical methods from the Scottish teams of Motherwell and Aberdeen. ${ }^{113}$ Less than two decades later, this search for knowledge and enjoyment of the game was to continue. Australian manager Dave Johnston remarked that 'your spectators have been most fair and encouraging ... and I should say they rank amongst the best soccer critics, while your Coloured, Indian and bantu enthusiasts also have a very good idea of the finer points of the game'. ${ }^{114}$ Not only did they know the finer points, but also the better players. On occasions they would cheer their hero, Cec Drummond, or Kevin O’Neill or other Australians who would kill off any attacks by the home team. ${ }^{115}$ The Australians accepted this adulation, yet there were no public statements condemning apartheid. The Australians' attitude on tour fitted with the policies of the new Liberal Prime Minister, Robert Menzies, who considered apartheid as 'a 
domestic issue, which should not concern the international community, and as a veiled threat to Australia's own restricted immigration policy'. ${ }^{116}$

The Australian tour highlighted the improvements the game had made. Following the fourth Test, Litchfield stated that the 'result of the series has "made" permanent home and away tours between the two countries. ${ }^{117}$ Litchfield's comments were echoed throughout both South African and Australian football administrations. Prior to the team's departure from Cape Town, Fred Fell, SAFA's chairman, discussed the matter with Dave Johnston. Fell had stated earlier that 'he favoured an annual exchange of visits'. His counterpart in Australia, Sydney Storey was of the same opinion. 'An interchange of tours will be beneficial to the Associations of both countries, which are not as far apart as most Soccer countries. It will allow both to send a team on tour without straining financial resources'. ${ }^{118}$ Yet, both Johnston and his fellow manager, Harold Barwick, left with a parting remark. Both believed that South Africa would require a much stronger team when they next toured Australia. Johnston predicted that increased immigration from Britain and Europe to Australia would help football grow with 'these new citizens injecting fresh blood in two to three years'. Johnston said 'I feel for the next Springbok team to tour Australia. Even if they come in two years’ time I don’t think they will win a major match'. ${ }^{119}$ The South Africans returned to Australia five years after the Australian visit and Johnston's prediction turned out to be wrong.

\section{The 1955 South African tour of Australia}


The successes of the 1950 tour would be quickly undone less than a year later and over the next five years Australia’s results would make a mockery of Johnston's predictions. Marking the golden jubilee of Federation in Australia, the English made their third tour of Australia in 1951 and home sides were comprehensively beaten in all of the games played. In 1953 a team from Hong Kong visited winning three and drawing one of six matches against Australia. Hosting New Zealand in 1954, Australia managed only two wins and a loss. Yet it would be the lead up games to the South African tour in 1955 that created the most concern. Rapid Vienna (Austria) and a team from South China visited at the same time. Australia could not cope and lost match after match. The selectors could not settle on a team choosing no less than 32 players for the first six Tests alone. The Australians faced the problem of selecting players from all states as the game remained organised on a state and local basis, while players only came together for international selection, friendly games or interstate matches. Andy Burton, former NSW team manager stated: 'You can’t expect cohesive football from players unaccustomed to each other'. ${ }^{120}$ Yet this lack of cohesion and lack of organisation was what lay before the Australian players and what the South Africans were to face.

During this period South African football saw the visits of a number of professional teams that included the Athletic Club of Portugal and Wolverhampton Wanderers (1951), Newcastle United (1952), Dundee United (1953) and Heart of Midlothian (1953/54). The South Africans arrived in Perth after a 36 hour flight in August 1955 and embarked on 15 match tour. Captain Gordon Frew and some of the players were reprimanded by the South African manager John Kennedy for talking to the press on arrival in Australia. ${ }^{121}$ After the scandals of the 1947 tour, Kennedy gave instructions 
to all his players that 'I am the manager and spokesman and all statements and interviews will come from me'. ${ }^{122}$ In the first game against a Western Australian XI, the traditional Afrikaans folk song 'Sarie Marais’ was played rather than South African apartheid anthem 'Die Stem' as the players lined up for the pre-match formalities. ${ }^{123}$ Thereafter a South African flag and recording of the anthem was obtained from the High Commissioner in Canberra. The Star noted that only three of the starting team were born in Australia, the rest originated from Britain and mainland Europe. $^{124}$

Prior to the arrival of the South Africans, the managers of the Rapid Vienna and South China teams voiced their opinions of their treatment by the Australians. Rapid Vienna's Lothar Bilek commented that 'we are disgusted with the way local referees allowed the Australians to get away with rough play', while South China's Chan said 'I doubt whether the Springboks will be able to follow the rulings by your referees. South China came here to play scientific soccer, but your players would not allow that style of play. They play the man instead of the ball far too much and the referees do little about it'. ${ }^{125}$ The South African team experienced a few injuries but according to Kennedy this was due to the 'very poor condition' of the playing surfaces with cricket pitches in the middle presenting 'another hazard' in addition to 'multiple markings often lead[ing] to confusion'. ${ }^{126}$ When the team arrived in Sydney they struck another impediment, the balls used in training were too soft and heavy for worthwhile practice. Yet these were not even at the ground when they commenced their first training session, the balls having to be asked for from the Soccer Club in George Street. ${ }^{127}$ The Star reported that in the game against Metropolis in Sydney 'several tackles [were] illegal ${ }^{128}$ and that five South Africans were injured. Of further concern 
was the small crowd of 4000 people who watched the South Africans in Sydney which only generated a gate of $£ 400 .{ }^{129}$ The South China football team voiced their unhappiness in the manner in which they had been treated while in Australia. Their manager remarked that the Australian officials were 'shoddy and discourteous...greedy over money and neglected even the most commonplace of courtesies... they would not spend a penny to help us...[and] made considerable profit out of us while we are going home with a loss...had it not been for our countrymen living in Australia ours would have been a cheerless tour' ${ }^{130}$ Kennedy reported to SAFA that accommodation 'left much to be desired [and] it was obvious that the tour had not been planned ahead'. ${ }^{131}$ Moreover, Kennedy requested SAFA to cable the touring party additional funds due to the high costs encountered in Australia. $^{132}$

The Star reported on the expected loss the Australian officials would incur. The tour had been underwritten for $£ 32,000$ but only £1,700 had been generated after two games. ${ }^{133}$ The South Africans request for an additional player be flown to Australia, after Gibson was injured, was rejected by the Australians who claimed the South Africans only played twice a week as compared to the Austrian and Chinese visitors who had played three times a week. In the first Test played in Brisbane, the South Africans ran out 3:0 winners in front of 6000 spectators. The Star exclaimed 'Australians [are] not up to standard of soccer Springboks'. ${ }^{134}$ It also reported that the Australian captain Joe Marston would not be available for the second Test as his club side required his services. ${ }^{135}$ Only 2000 people watched the second Test match in Melbourne. ${ }^{136}$ For the third Test, the Australians were trounced 8:0. The Star reported that 'the Springboks look like being Australia's masters for some time to come'. ${ }^{137}$ 
Moreover, the paper correctly predicted the South African domination would 'end the interchange of visits between the countries', while 'the Springboks are unbeaten on tour but cannot pull the crowds' ${ }^{138}$ Prior to the final Test in Newcastle it was reported that 'there is not a great deal of interest' in the match and for the South Africans it had 'not been a happy tour' as they arrived at the end of the season while the Australians had 'too much international soccer' during the season. ${ }^{139}$ The final two Tests proved farcical when Australian spectators rather than booing their team began to laugh. The Sunday Telegraph stated that 'this was the greatest insult the code has suffered this season'. ${ }^{140}$ The South Africans went unbeaten on their 1955 tour scoring 62 goals while only conceding $15 .{ }^{141}$ Pat Murray, the South African soccer assistant manager suggested the press 'never praise our game...[and] detract from the merit of the Springbok...when Austria [sic] and South China won matches they were praised for excellent soccer. The Springboks would like the same kudos’. ${ }^{142}$ The tour had been scheduled at the wrong time, at the end of the season and Australian football official Storey conceded that having the Austrians and Chinese tour before the South Africans had been a 'mistake'. ${ }^{143}$

The Australians suffered significantly from the three tours and the managers from Rapid Vienna and South Africa both offered their advice. The problems that had beset the Australians were many which their captain Bob Bignell simply summarised as the players 'met as a team for the first time on Saturday morning'. Eventually there would be 38 individuals chosen for the 13 Test matches. ${ }^{144}$ Prior to departure, Kennedy noted to his amazement that he imagined 'a panel of about 16 players would have been chosen and developed into a combination with constructive coaching just like a touring overseas side. My players figured we would be opposed by a well-coached 
Test team. Instead we saw new faces new faces in each Test' ${ }^{145}$ He also remarked that despite the influx of immigrants into Australia the standard of play had deteriorated as the 'game is going through a period of transition...[and they have] not yet decided which style to follow' ${ }^{146}$ Yet, only one new Australian was selected, and only for the Fourth Test. That led Max Gold, the Vienna coach, to put forward a fivepoint plan to help bring the game of football in Australia a much required boost, the most important of these points being their own enclosed fields. ${ }^{147}$ The Star reported that 'football followers in the Union would never be attracted by Australian touring teams'. ${ }^{148}$

\section{Conclusion}

South African football authorities were keen to pit themselves against their Australian and New Zealand counterparts and contacts developed prior to the First World War. The rationale was to build ties and compete against other Dominions while maintaining strong links to Britain. However the first tour to Australia and New Zealand only occurred after the end of the Second World War. Three tours took place against the backdrop of the British Empire that was beginning to unravel while within South Africa apartheid was about to be unveiled. The South Africans performed particularly well in Australia in 1947 and despite the scandals that engulfed the 1947 tour, the South African authorities invited their counterparts to tour. The Australian tourists of 1950 were not expected to fare well against the South Africans. However, this was not the case as the Australians performed exceptionally and returned confident that South Africa would never beat them again. The 1955 tour revealed the gulf that had emerged between South African and Australian football. Despite both countries facing stiff opposition from other winter sports, the South Africans were 
organisationally efficient, financially strong and superior on the field of play to the Australians. After 1955 South African football enjoyed the visit of an English FA side in 1956 while a South African side toured Britain in 1958. In 1959, 'white’ football was transformed when the National Football League was established. The new 'whites-only' league introduced semi-professional football which saw 'white' football reach its zenith in the latter part of the 1960s which was followed by its rapid decline in the 1970s.

Australia's decline took place much earlier. The over-confidence of their abilities together with the general lack of direction from the governing body created a false sense of superiority that was clearly exposed in 1955. Their strong results in South Africa in 1950 fed an Australian eagerness to promote the game. Yet the Australian Soccer Football Association did not capitalise on the gain, leaving the game to suffer. The decision to host three touring sides in 1955 proved exhausting for players and spectators alike. The South African tour suffered financially, and a year before the 1956 Melbourne Olympic Games had not promoted association football in the manner the organisers had hoped for. At the beginning of 1955 Rugby League were worried about the impending rise of football through the tours, yet after the dismal performances 'must have chuckled as they saw Soccer gradually losing its grip on the public' ${ }^{149}$ It would be another twelve years before a country toured Australia, Japan in 1968. Further, in 1970 Australia finally made its first tour to Europe and other parts of the World. Australia and South Africa, though, would have to wait 39 years when a non-racial South African team met Australia in Adelaide. 


\section{References}

Alegi, Peter. 'Playing to the Gallery: Sport, Cultural Performance and Social Identity in South Africa, 1920s-1945’. International Journal of African Historical Studies, 35, no. 1 (2002): 17-38.

Allen, Dean. 'Tours of Reconciliation: Rugby, War and Reconstruction in South Africa, 1891-1907’', Sport in History, 27, no. 2 (2007): 172-189.

Archer, Robert, and Antoine Bouillon. The South African Game: Sport and Racism. Wesport, CN: L. Hill, 1982.

Black, David R., and John Nauright. Rugby and the South African Nation. Manchester: University Press, 1998.

Blainey, Geoffrey. The Tyranny of Distance: How Distance Shaped Australia's History. Melbourne: Sun Books, 1966.

Bolsmann, Chris. 'White Football in South Africa: Empire, Apartheid and Change, 1892-1977’. Soccer and Society, 11, nos. 1-2 (2010): 29-45.

Bolsmann, Chris. 'South African Football Tours at the turn of the Twentieth Century: Amateurs, Pioneers and Profits'. African Historical Review, 42, no. 2 (2010): 91-112. 
Bolsmann, Chris. 'The 1899 Orange Free State Football Team of Europe: 'Race', Imperial Loyalty and Sports Spectacle'. International Journal of the History of Sport, 28, no. 1 (2011): 81-97.

Bridge, Carl. 'Introduction: Australia's changing relations with Britain and the Commonwealth from Menzies to Howard via Fraser - A brief survey'. The Round Table, 95, no. 387 (2006): 661-5.

Caldwell, Geoffrey. 'Sport and the Australian Identity', in Sport in Australia:

Selected readings in physical activity, ed. T. D. Jacques and G. R. Pavia, 140-7. Parramatta: Macarthur Press, 1976.

Cashman, Richard. Sport in the National Imagination: Australian Sport in the Federation Decades. Sydney: Walla Walla Press, 2002.

Gemmell, Jon. “"The Springboks are not a Test Side”: the foundation of the Imperial Cricket Conference’ Sport in Society, 14, no. 5 (2011): 701-18.

Guoth, Nick. 'Kangaroos and Dragons: The 1923 Chinese Football Tour of Australia'. Masters thesis, Australian National University, 2010.

Guoth, Nick. ‘Kindred Sports: Rugby Union’s Involvement with the 1922 Australian Soccer Tour', in Football Fever: Crossing Boundaries, ed. Rob Hess, Matthew Nicholson and Bob Stewart, 17-25. Melbourne: Maribyrnong Press, 2005 
Hallinan, Chris, and John Hughson, eds. The Containment of Soccer in Australia: Fencing Off the World Game. London: Routledge, 2010.

Hay, Roy. 'Black (Yellow or Green) Bastards: Soccer Refereeing in Australia: A Much Maligned Profession’, Sporting Traditions, 15, no. 2 (1999): 19-36.

Hay, Roy. 'Our Wicked Foreign Game’: Why has Association Football (Soccer) not become the Main Code of Football in Australia?', Soccer \& Society, 7, nos. 2-3 (2006): 165-86.

Hay, Roy. 'A gentle giant of the times’. Goal Weekly, August 17, 2009.

Holt, Richard. Sport and the British: A Modern History. Oxford: Clarendon Press, 1989.

Honey, Andrew. 'Sport, Immigration Restriction and Race: The operation of the White Australia Policy’, in Sport, Federation, Nation, ed. John O'Hara, Richard Cashman, and Andrew Honey, 26-46. Sydney: Walla Walla Press. 2001.

Kreider, Richard. The Soccerites. Perth: Sports West Media, 2005.

Levett, Geoff. 'Constructing Imperial Identity: The 1907 South African Tour of England', in Empire and Cricket: The South African Experience 1884-1914, ed. Bruce Murray and Goolam Vahed, 241-58. Pretoria: University of South Africa Press, 2009. 
Markus, Andrew. 'Government Control of Chinese Immigration to Australia, 18551975', in The Overseas Chinese in Australasia: History, Settlement and Interactions, ed. Henry Chan, Ann Curthoys, and Nora Chiang, 69-81. Canberra: Centre for the Chinese Southern Diaspora, Australian National University, 2001.

Mosely, Philip A. and Bill Murray. 'Soccer', in Sport in Australia: A Social History, ed. Wray Vamplew, Brian Stoddart and Ian F. Jobling, 213-30. Cambridge: Cambridge University Press, 1994.

Murray, Bill, and Roy Hay, eds. The World Game Downunder. Melbourne: Australian Society for Sports History, 2006.

Murray, Bruce, and Goolam Vahed, eds. Empire and Cricket: The South African Experience 1884-1914. Pretoria: University of South Africa, 2009.

Nauright, John, and David Black, “"Hitting them Where it Hurts”: Springbok-All Black Rugby, Masculine National Identity and Counter-Hegemonic Struggle, 19591992', in Making Men: Rugby and Masculine Identity ed. John Nauright and Timothy J. L. Chandler, 205-26. London: Frank Cass, 1996.

Pascoe, Rob. The Winter Game: The Complete History of Australian Football. Melbourne: Text Publishing Company, 1995. 
Pearson, Michael N., 'Heads in the Sand: the 1956 Springbok Tour to New Zealand in Perspective', in Sport in History: the Making of Sporting History, ed. Richard Cashman and Michael McKernan, 272-92. St. Lucia: The University of Queensland Press, 1979.

Pollard, Jack. Rugby Union: The Game and the Players. Sydney: Angus and Robertson, 1984.

Ryan, Greg. 'Anthropological Football: Maori and the 1937 Springbok Rugby tour of New Zealand'. New Zealand Journal of History, 34, no. 1 (2000): 60-79.

Shnaps, Teddy T. 'South Africa vs. New Zealand, 1921-1970. 50 years of international tours and test matches', in Good-bye Newlands, farewell Eden Park. ed. Fred Labuschagne, Cape Town: Howard Timmins, 1974.

Syson, Ian. 'The Genesis of Soccer in Australia'. The Conversation, 25 July 2011, http://theconversation.edu.au/the-genesis-of-soccer-in-australia-2466, (accessed September 7, 2011)

Stoddart, Brian. 'Sport, Cultural Imperialism, and Colonial Response in the British Empire’. Comparative Studies in Society and History 30, no. 4 (1988): 649-73.

Vamplew, Wray, Katherine Moore, John O’Hara, Richard Cashman, and Ian F. Jobling, eds. The Oxford Companion to Australian Sport. Oxford: Oxford University Press, 1992. 
Van Der Merwe, Floris J. G. 'Race and South African rugby: a review of the 1919

“All Black” tour’. South African Journal for Research in Sport, Physical Education

and Recreation, 32, no. 2 (2010): 161-169.

Winch, Jonty. 'Guardians of the Game: The Role of the Press in Popularising the

1888/89 tour and Establishing the South African Cricket Association', in Empire and

Cricket: The South African Experience 1884-1914 ed. Bruce Murray and Goolam

Vahed, 45-60. Pretoria: University of South Africa, 2009.

\footnotetext{
${ }^{1}$ The authors acknowledge the valuable insights and suggestions provided by the two anonymous reviewers and Editor Rob Hess.

${ }^{2}$ West Australian, 15 April 1947, p. 4.

${ }^{3}$ See for example Cashman Sport and the National Imagination; Gemmell, 'The Springboks are not a Test side'; Murray and Vahed, Empire and Cricket; Nauright and Black 'Hitting them Where it Hurts'; Pearson 'Heads in the Sand' and Ryan 'Anthropological Football'.

${ }^{4}$ Cashman unveils the need for further exploration of sporting contacts between the two countries during the twentieth century. Cashman, The Imaginary Grandstand, 153.

${ }^{5}$ These organisations were established for 'white' male South Africans only. Others in South African followed suit as in the case of the South African Indian Football Association established in 1903. See Archer South African Game, 99.

${ }^{6}$ See Winch, 'Guardians of the Game', 45-60.

7 See Bolsmann 'South African Football Tours' and Bolsmann 'The 1899 Orange Free State Football' for a discussion of early football tours.

${ }^{8}$ See for example Black and Nauright Rugby and the South African Nation; Levett, 'Constructing Imperial Identity', and Allen, 'Tours of Reconciliation'.

${ }_{9}^{9}$ Advertiser, 19 May 1919, p. 8; Van Der Merwe, 'Race and South African rugby'; Shnaps, 'South Africa vs New Zealand'.

${ }^{10}$ See Blainey The Tyranny of Distance.

${ }^{11}$ All three codes were run through Sydney and while union and league were financially strong, association football was not. See Hay 'Our Wicked Foreign Game’.

${ }^{12}$ Holt Sport and the British, 237.

13 Stoddart 'Sport', 651.

${ }^{14}$ Caldwell, 'Sport and the Australian', 142.

15 The Trove digitisation project of the National Library of Australia has unveiled numerous unknown historical facts, the latest being match reports of games played in the early 1870s in Brisbane. See Syson 'The genesis of soccer in Australia'.

${ }^{16}$ See Bolsmann 'White football in South Africa'; Kreider, Soccerites, 23-25; Sydney Morning Herald, 17 May 1882, p. 6.

${ }^{17}$ Australasian Association Football Conference, Minutes, 15-16 and 21 December 1911.

${ }^{18}$ Pascoe The Winter Game, 77; Pollard Australian Rugby Union, 47; Vamplew, et al The Oxford Companion, 34.
} 
${ }^{19}$ See Guoth 'Kangaroos and Dragons' and Guoth 'Kindred Sports' for discussions on the 1923 Chinese tour and the 1922 Australian tour to New Zealand.

${ }^{20}$ New South Wales Soccer Football Association (NSWSFA) Annual Report for 1925, The Alert Printing and Publishing Co., Sydney, 1926. p. 13.

${ }^{21}$ Only a few tours have been dissected yet for a general overview of football in Australia and the tours see Mosely and Murray 'Soccer', pp. 218-221, Murray and Hay The World Game and Hallinan and Hughson The Containment.

${ }^{22}$ Markus 'Government control of Chinese Immigration', 73.

${ }^{23}$ Honey 'Sport, Immigration, Restriction and Race', 31, 38, 42.

${ }^{24}$ South African Football Association (SAFA) Minutes 10 February 1909. Historical Papers Collection, William Cullen Library, University of the Witwatersrand, AG3827; Ashburton Guardian, 22 April 1909, p. 3.

${ }^{25}$ Finance appeared to be the concern given that the NZFA needed the provincial associations to assist. Evening Post, 8 May 1909, p. 14; SAFA AGM 9 August 1909. Historical Papers Collection, William Cullen Library, University of the Witwatersrand, AG3827

${ }^{26}$ SAFA Minutes 7 August 1925. Historical Papers Collection, William Cullen Library, University of the Witwatersrand, AG3827

${ }^{27}$ NSWSFA Annual Report for 1925, p. 9; Sunday Times, 2 August 1925, p. 7.

${ }^{28}$ SAFA minutes 30 April 1927 and 6 August 1927. Historical Papers Collection, William Cullen Library, University of the Witwatersrand, AG3827.

${ }^{29}$ NSWSFA Annual Report for 1927, The Bexley Press, Sydney, 1928, p. 16.

${ }^{30}$ SAFA Minutes 13 October 1927. Historical Papers Collection, William Cullen Library, University of the Witwatersrand, AG3827; NSWSFA Annual Report for 1927, The Bexley Press, Sydney, 1928, p. 16.

${ }^{31}$ Letter from Transvaal Football Association to SAFA 4 December 1927. Historical Papers Collection, William Cullen Library, University of the Witwatersrand, AG3827.

${ }^{32}$ SAFA AGM 6 March 1931. Historical Papers Collection, William Cullen Library, University of the Witwatersrand, AG3827.

${ }^{33}$ SAFA AGM 12 March 1932. Historical Papers Collection, William Cullen Library, University of the Witwatersrand, AG3827.

${ }^{34}$ Morning Bulletin, 17 May 1938, p. 11.

${ }^{35}$ Advertiser, 1 May 1939, p. 7; Cairns Post, 23 November 1939, p. 10.

${ }^{36}$ The Argus, 14 August 1939, p. 16.

${ }^{37}$ SAFA Minutes 5 December 1937. Historical Papers Collection, William Cullen Library, University of the Witwatersrand, AG3827.

${ }^{38}$ SAFA Minutes 6 September 1945. Historical Papers Collection, William Cullen Library, University of the Witwatersrand, AG3827.

${ }^{39}$ Rand Daily Mail, 22 January 1947, p. 11.

${ }^{40}$ West Australian, 12 April 1947, p. 10.

${ }^{41}$ Rand Daily Mail, 28 March 1947, p. 11.

${ }^{42}$ SAFA Minutes 7 March 1947. Historical Papers Collection, William Cullen Library, University of the Witwatersrand, AG3827.

${ }^{43}$ Cape Times, 19 April 1947, p. 15.

${ }^{44}$ The Star, 29 April 1947, p. 11.

${ }^{45}$ The Star, 1 May 1947, p. 1.

${ }^{46}$ Ibid.

${ }^{47}$ Ibid.

${ }^{48}$ Rand Daily Mail, 5 May 1947, p. 9; Daily Telegraph, 2 May 1947, p. 24.

${ }^{49}$ Daily Telegraph, 30 April 1947, p. 28.

${ }^{50}$ The Star, 2 May 1947, p. 11.

${ }^{51}$ The Star, 5 May 1947, p. 11

${ }^{52}$ Quoted in Rand Daily Mail, 7 May 1947, p. 11.

${ }^{53}$ Daily Telegraph, 5 May 1947, p. 19.

${ }^{54}$ Rand Daily Mail, 12 May 1947. p. 9.

${ }^{55}$ The Star, 9 May 1947, p. 11.

${ }^{56}$ Ibid.

${ }^{57}$ Rand Daily Mail, 9 June 1947, p. 11.

${ }^{58}$ Ibid.

${ }^{59}$ Rand Daily Mail, 13 June 1947, p. 11. 
${ }^{60}$ Rand Daily Mail, 17 June 1947, p. 11.

${ }^{61}$ Rand Daily Mail, 18 June 1947, p. 4.

${ }^{62}$ SAFA, Circular to Divisional Associations, February 1, 1930. Historical Papers Collection, William Cullen Library, University of the Witwatersrand, AG3827.

${ }^{63}$ The Star, 20 June 1947, p. 11.

${ }^{64}$ Ibid.

${ }^{65}$ Van Der Merwe, 'Race and South African rugby’.

${ }^{66}$ Quoted in Ryan, 'Anthropological Football'.

${ }^{67}$ See Ryan 'Anthropological Football' for an excellent discussion of the incident and for reframing the debate on sporting contacts between New Zealand and South Africa.

${ }^{68}$ Ibid.

${ }^{69}$ The Christchurch Star-Sun 26 June 1947, p. 3.

${ }^{70}$ Ibid.

${ }^{71}$ Ibid.

${ }^{72}$ Rand Daily Mail, 27 June 1947, p. 11.

${ }^{73}$ The Star, 27 June 1947, p. 11.

${ }^{74}$ Rand Daily Mail, 1 July 1947, p.11.

${ }^{75}$ The Star, 28 June 1948, p. 11.

${ }^{76}$ The Star, 8 July 1947, p. 11.

${ }^{77}$ Ibid.

${ }^{78}$ Daily Telegraph, 27 June 1947, p. 23.

${ }^{79}$ The Star, 16 July 1947.

${ }^{80}$ Rand Daily Mail, 12 August 1947, p. 11.

${ }^{81}$ The reports were not found in the archives of the South African Football Association.

${ }^{82}$ The Star, 11 December 1947, p. 12.

${ }^{83}$ SAFA Private Minutes of Special General Meeting 28 May 1948. Historical Papers Collection, William Cullen Library, University of the Witwatersrand, AG3827.

${ }^{84}$ SAFA Minutes 29 January 1948. Historical Papers Collection, William Cullen Library, University of the Witwatersrand, AG3827.

${ }^{85}$ SAFA Private Minutes of Special General Meeting 28 May 1948.

${ }^{86}$ SAFA Minutes 18 October 1947. Historical Papers Collection, William Cullen Library, University of the Witwatersrand, AG3827.

${ }^{87}$ The Star, 17 June 1947, p. 11.

${ }^{88} 1947$ tour results: 19/04/1947 South Africa 12 d. Western Australia 2 (Perth); 26/04/1947 South Africa 3 d. Australian XI 2 (Adelaide); 30/04/1947 South Africa 5 d. Australian XI 4 (Melbourne); 3/05/1947 South Africa 5 d. New South Wales 4 (Sydney); 7/05/1947 South Africa 2 d. South Coast 1 (Wollongong); 10/05/1947 South Africa 2 d. Australia 1 (Sydney) (TEST); 13/05/1947 South Africa 5 d. Northern Districts 1 (Cessnock); 17/05/1947 South Africa 10 d. Queensland 1 (Brisbane); 21/05/1947 South Africa 9 d. Brisbane 1 (Brisbane); 24/05/1947 South Africa 4 d. Australia 2 (Brisbane) (TEST); 27/05/1947 South Africa 5 d. Ipswich 0 (Ipswich);

31/05/1947 South Africa 3 drew Australia 3 (Sydney) (TEST); 4/06/1947 South Africa 3 d. Northern Districts 1 (Newcastle); 7/06/1947 Australia 5 d. South Africa 1 (Newcastle) (TEST); 11/06/1947 South Africa 2 d. South Coast 0 (Bulli); 14/06/1947 South Africa 2 d. Australia 1 (Sydney) (TEST); 16/06/1947 South Africa 2 d. New South Wales 1 (Sydney); 21/06/1947 South Africa 3 drew Auckland 3 (Auckland); 26/06/1947 South Africa 7 d. Wellington 1 (Wellington); 28/06/1947 South Africa $6 \mathrm{~d}$. New Zealand 5 (Dunedin) (TEST); 2/07/1947South Africa 8 d. Otago 0 (Dunedin); 5/07/1947 South Africa 6 d. New Zealand 0 (Christchurch) (TEST); 9/07/1947 South Africa 6 d. Canterbury 1 (Christchurch); 12/07/1947 South Africa 8 d. New Zealand 3 (Wellington) (TEST); 16/07/1947 South Africa 10 d. South Auckland-Poverty Bay 0 (Hamilton); 19/07/1947 South Africa 4 d. New Zealand 1 (Auckland) (TEST); 23/07/1947 South Africa 3 drew Auckland 3 (Auckland); 26/07/1947 Northern Districts 2 d. South Africa 1 (Newcastle); 30/07/1947 South Africa 9 d. Goulburn 0 (Goulburn); 2/08/1947 South Africa 4 d. Victoria 0 (Melbourne); 6/08/1947 South Africa 8 d. South Australia 0 (Adelaide); 9/08/1947 South Africa 7 d. South Australia 0 (Adelaide); 16/08/1947 South Africa 7 d. Lithgow Districts 0 (Lithgow).

${ }^{89}$ Ibid.

${ }^{90}$ Ibid.

${ }^{91}$ Sydney Morning Herald, 20 February 1948, p. 7.

${ }^{92}$ Sydney Morning Herald, 18 September 1948, p. 7. 
${ }^{93}$ SAFA Minutes, 3 December 1948. Historical Papers Collection, William Cullen Library, University of the Witwatersrand, AG3827.

${ }^{94}$ Sydney Morning Herald, 8 March 1949, p. 6.

${ }^{95}$ The Football Association Empire Conference London Minutes of informal meeting 6 August 1948

${ }^{96}$ Sydney Morning Herald, 8 March 1949, p. 6.

${ }^{97}$ SAFA Minutes, 6 November 1949. Historical Papers Collection, William Cullen Library, University of the Witwatersrand, AG3827; Sydney Morning Herald, 27 October 1949, 10.

${ }_{98}^{98}$ Sydney Morning Herald, 7 November 1949, p. 7.

${ }^{99}$ Sydney Morning Herald, 21 January 1950, p. 8.

${ }^{100}$ Sydney Morning Herald, 14 February 1950, p. 8.

${ }^{101}$ Ten players came from New South Wales and a number of papers from around Australia placed some emphasis on this fact. Victoria had three chosen, Queensland two and South Australia one.

Eventually Victorian Kennedy was to withdraw with New South Wales player Cyril Nicholls replacing him, thus adding further fuel to those who believed New South Wales was getting preference. See Hay 'A gentle giant'.

${ }^{102}$ Daily Telegraph, 1 May 1950, p. 23.

${ }^{103}$ West Australian, 5 May 1950, p. 26; Advertiser, 19 May 1950, 16; Pretoria News, 23 May 1950, p. 8.

${ }^{104}$ Advertiser, 23 February 1950, p. 8.

${ }^{105}$ The Star, 26 May 1950, p. 18.

${ }^{106}$ Rand Daily Mail, 27 May 1950, p. 12.

${ }^{107}$ Courier Mail, 31 July 1950, p. 9.

${ }^{108} 1950$ tour results: 24/05/1950 Australia 2 d. Western Province 1 (Cape Town); 27/05/1950 Australia 1 drew Southern Transvaal 1 (Johannesburg); 31/05/1950 Northern Transvaal 5 d. Australia 3 (Pretoria); 3/06/1950 Natal 2 d. Australia 1 (Durban); 7/06/1950 Australia 2 d. Orange Free State 1 (Bloemfontein); 10/06/1950 Australia 2 drew Eastern Transvaal 2 (Benoni); 14/06/1950 Australia 5 d. Southern Rhodesia 0 (Salisbury); 17/06/1950 Australia 4 d. Southern Rhodesia 1 (Bulawayo); 21/06/1950 Natal 3 d Australia 2 (Pietermaritzburg); 24/06/1950 South Africa 3 d. Australia 2 (Durban) (TEST); 28/06/1947 Australia 9 d. Northern Transvaal Districts 0 (Witbank); 1/07/1947 South Africa 2 d. Australia 1 (Johannesburg) (TEST); 8/07/1947 Australia 2 d. South Africa 1 (Port Elizabeth) (TEST); 12/07/1950 Australia 7 d. Griqualand West 3 (Kimberley); 15/07/1950 Australia 4 d. Frontier 0 (East London); 19/07/1950 Australia 13 d. South Western Country 0 (Mossel Bay); 22/07/1950 Australia 2 d. South Africa 0 (Cape Town) (TEST); 29/07/1950 Australia 3 drew Western Province 3 (Cape Town).

${ }^{109}$ Daily Telegraph, 3 July 1950, p. 17. While the tradition of the Ashes is a cricket phenomenon dating to 1882, Association Football in Australia, since 1923, has also considered Test series to be played for the Ashes.

${ }^{110}$ Sunday Times, 30 April 1950, p. 42.

${ }^{111}$ The Star, 12 June 1950, 14; The Rhodesia Herald, 18 June 1950, p. 18.

${ }_{112}$ Daily Telegraph, 30 May 1950, p. 24; 2 June 1950, p. 29; Rand Daily Mail, 2 June 1950, p. 12.

${ }_{113}^{113}$ Alegi, 'Playing to the Gallery', 32.

${ }^{114}$ The Star, 20 July 1950, p. 18.

${ }^{115}$ The Star, 24 July 1950, p. 16.

${ }^{116}$ Bridge, 'Australia’s Changing Relations', 662.

${ }^{117}$ Rand Daily Mail, 24 July 1950, p. 12.

${ }^{118}$ Daily Telegraph, 31 July 1950, p. 19.

${ }^{119}$ The Star, 11 July 1950, p. 16; Rand Daily Mail, 24 July 1950, p. 12.

${ }^{120}$ Daily Telegraph, 10 August 1955, p. 32.

${ }^{121}$ Rand Daily Mail, 17 August 1955, p. 12.

${ }^{122}$ Rand Daily Mail, 17 August 1955, p. 12.

${ }^{123}$ SAFA Report on Tour of Australia by the South African Springbok Team 1955. Historical Papers Collection, William Cullen Library, University of the Witwatersrand, AG3827.

${ }^{124}$ The Star, 16 August 1955, p. 20.

${ }^{125}$ Sydney Morning Herald, 18 August 1951, p. 62; Rand Daily Mail, 19 August 1955, p. 12. See Hay 'Black (Yellow or Green)'

${ }^{126}$ SAFA Report on Tour of Australia by the South African Springbok Team 1955. Historical Papers Collection, William Cullen Library, University of the Witwatersrand, AG3827.

${ }^{127}$ Daily Telegraph, 23 August 1955, p. 27.

${ }^{128}$ The Star, 24 August 1955, p. 24. 
${ }^{129}$ The Star, 25 August 1955, p. 24.

${ }^{130}$ Ibid.

${ }^{131}$ SAFA Report on Tour of Australia by the South African Springbok Team 1955. Historical Papers

Collection, William Cullen Library, University of the Witwatersrand, AG3827

${ }^{132}$ SAFA 30 September 1955.

${ }^{133}$ The Star, 26 August 1955, p. 24

${ }^{134}$ The Star, 5 September 1955, p. 20

${ }^{135}$ Daily Telegraph, 7 September 1955, p. 31; The Star, 8 September 1955, p. 24

${ }^{136}$ The Star, 12 September 1955, p. 23

${ }^{137}$ The Star, 19 September 1955, p. 23

${ }^{138}$ The Star, 21 September 1955, p. 24

${ }^{139}$ The Star, 23 September 1955, p. 24

${ }^{140}$ The Star, 24 September 1955, p. 14; Sunday Telegraph, 25 September 1955, p. 32.

${ }^{141} 1955$ tour results: 20/08/1955 South Africa 2 d. Western Australia 1 (Perth); 24/08/1955 South Africa 4 d. Metropolis 2 (Sydney); 27/08/1955 South Africa 2 d. New South Wales 0 (Sydney); 31/08/1955 South Africa 3 d. Queensland 2 (Brisbane); 3/09/1955 South Africa 3 d. Australia 0 (Brisbane) (TEST); 7/09/1955 South Africa 3 d. Victoria 2 (Melbourne); 10/09/1955 South Africa 2 d. Australia 0 (Melbourne) (TEST); 14/09/1955 South Africa 7 d. South Australia 1 (Adelaide); 17/09/1955 South Africa 8 d. Australia 0 (Adelaide) (TEST); 19/09/1955 South Africa 4 d. South Australia Continental 1 (Adelaide); 24/09/1955South Africa 6 d. Australia 0 (Sydney) (TEST); 28/09/1955 South Africa 4 d. Northern District 1 (Cessnock); 1/10/1955 South Africa 4 d. Australia 1 (Newcastle) (TEST); 2/10/1955 South Africa 8 d. South Coast 3 (Wollongong); 4/10/1955 South Africa 2 d. Western Australia 1 (Perth).

${ }_{142}$ Rand Daily Mail, 27 September 1955.

${ }^{143}$ The Star, 4 October 1955, p. 24

${ }^{144}$ Sun, 28 September 1955, p. 72.

${ }^{145}$ Sun, 4 October 1955, p. 61.

${ }^{146}$ The Star, 8 October 1955, p. 1. In the late 1940s and through the 1950s many Central and Southern Europeans migrated to Australia. These were termed by the existing population as New Australians.

${ }^{147}$ Sunday Telegraph, 21 August 1955, p. 35.

${ }^{148}$ The Star, 21 September 1955, p. 24.

${ }^{149}$ Sun, 28 September 1955, p. 72. 